\title{
Phytoplankton chlorophyll distributions and primary production in the Southern Ocean
}

\author{
J. Keith Moore ${ }^{1}$ and Mark R. Abbott \\ College of Oceanic and Atmospheric Sciences, Oregon State University, Corvallis
}

\begin{abstract}
Satellite ocean color data from the Sea-viewing Wide Field-of-view Sensor (SeaWiFS) were used to examine distributions of chlorophyll concentration within the Southern Ocean for the period October 1997 through September 1998. Over most of the Southern Ocean, mean chlorophyll concentrations remained quite low $\left(<0.3-0.4 \mathrm{mg} \mathrm{m}^{-3}\right)$. Phytoplankton blooms where chlorophyll concentration exceeded $1.0 \mathrm{mg} \mathrm{m}^{-3}$ were observed in three general areas, which included coastal/shelf waters, areas associated with the seasonal sea ice retreat, and the vicinity of the major Southern Ocean fronts. These chlorophyll distribution patterns are consistent with an iron-limited system. Mean chlorophyll concentrations from SeaWiFS are compared with values from the coastal zone color scanner (CZCS). The SeaWiFS global chlorophyll algorithm works better than the CZCS in Southern Ocean waters. Primary production in the Southern Ocean was estimated with the vertically generalized production model of Behrenfeld and Falkowski [1997]. Annual primary production in the Southern Ocean $\left(>30^{\circ} \mathrm{S}\right)$ was estimated to be

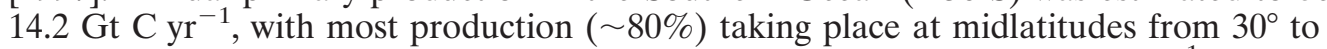

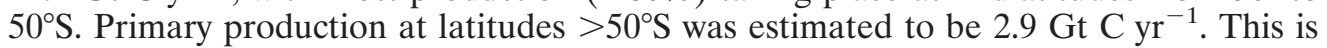
considerably higher than previous estimates based on in situ data but less than some recent estimates based on CZCS data. Our estimated primary production is sufficient to account for the observed Southern Hemisphere seasonal cycle in atmospheric $\mathrm{O}_{2}$ concentrations.
\end{abstract}

\section{Introduction}

Phytoplankton bloom dynamics in the Southern Ocean have long represented a paradox for oceanographers. Despite high concentrations of available nitrate and phosphate, chlorophyll concentrations in open ocean waters remain low (typically $<0.5 \mathrm{mg} \mathrm{m}^{-3}$ ) [Tréguer and Jacques, 1992; Comiso et al., 1993; Banse, 1996]. The Southern Ocean is thus the largest highnutrient low-chlorophyll (HNLC) region in the world ocean [Martin, 1990; Minas and Minas, 1992]. In recent years, substantial evidence has accumulated that the availability of the micronutrient iron plays a critical role in limiting phytoplankton biomass and production within HNLC regions [Martin et al., 1990a, 1990b; de Baar et al., 1995; Coale et al., 1996; Gordon et al., 1997; van Leeuwe et al., 1997; Takeda, 1998].

There have been several satellite-based studies of Southern Ocean phytoplankton dynamics that relied on data from the coastal zone color scanner (CZCS). Arrigo and McClain [1994] used CZCS data to estimate primary production in the Ross Sea. Several studies combined CZCS data with satellitederived ice cover information to examine ice edge phytoplankton bloom dynamics [Sullivan et al., 1988; Comiso et al., 1990].

Comiso et al. [1993] examined CZCS pigment data for the entire Southern Ocean and analyzed their relationship to several geophysical features. They noted that phytoplankton blooms occur primarily in several regions including areas as-

\footnotetext{
${ }^{1}$ Now at Advanced Studies Program, National Centers for Atmospheric Research, Boulder, Colorado.

Copyright 2000 by the American Geophysical Union.

Paper number 1999JC000043.

0148-0227/00/1999JC000043\$09.00
}

sociated with sea ice retreat, shallow waters, areas of strong upwelling, and regions of high eddy kinetic energy (mainly associated with Southern Ocean fronts) [Comiso et al., 1993]. The strongest correlation with pigments was a negative correlation between ocean depth and pigment concentrations, possibly the result of higher available iron concentrations in shallow water regions [Comiso et al., 1993]. Sullivan et al. [1993] also examined CZCS pigment data for the whole Southern Ocean. They noted intense phytoplankton blooms within and downstream of coastal/shelf areas, which they attributed to elevated iron availability [Sullivan et al., 1993]. Silicic acid availability may limit diatom production and biomass accumulation in several areas [Tréguer and Jacques, 1992; Sullivan et al., 1993]. Mitchell and Holm-Hansen [1991] developed a regional Southern Ocean pigment (SOP) retrieval algorithm for the CZCS on the basis of the bio-optical properties of Antarctic Peninsula waters. This regional pigment algorithm was deemed necessary because the global pigment (GP) algorithm for CZCS [Gordon et al., 1983] resulted in underestimates of surface chlorophyll concentrations in Southern Ocean waters [Mitchell and Holm-Hansen, 1991; Sullivan et al., 1993; Arrigo et al., 1994]. Arrigo et al. [1994] provided correction factors for converting GP pigment estimates to SOP pigment values. The SOP pigment values are higher than the GP estimates by a factor ranging from $\sim 2.1$ to 2.5 for chlorophyll concentrations below $1.5 \mathrm{mg} \mathrm{m}^{-3}$ [Arrigo et al., 1994].

In this study, Sea-viewing Wide Field-of-view Sensors (SeaWiFS) satellite-based estimates of surface chlorophyll concentrations are used to examine phytoplankton biomass distributions and dynamics within the Southern Ocean. We use a broad definition for the Southern Ocean encompassing the area from the Antarctic continent north to $30^{\circ} \mathrm{S}$. This northern 



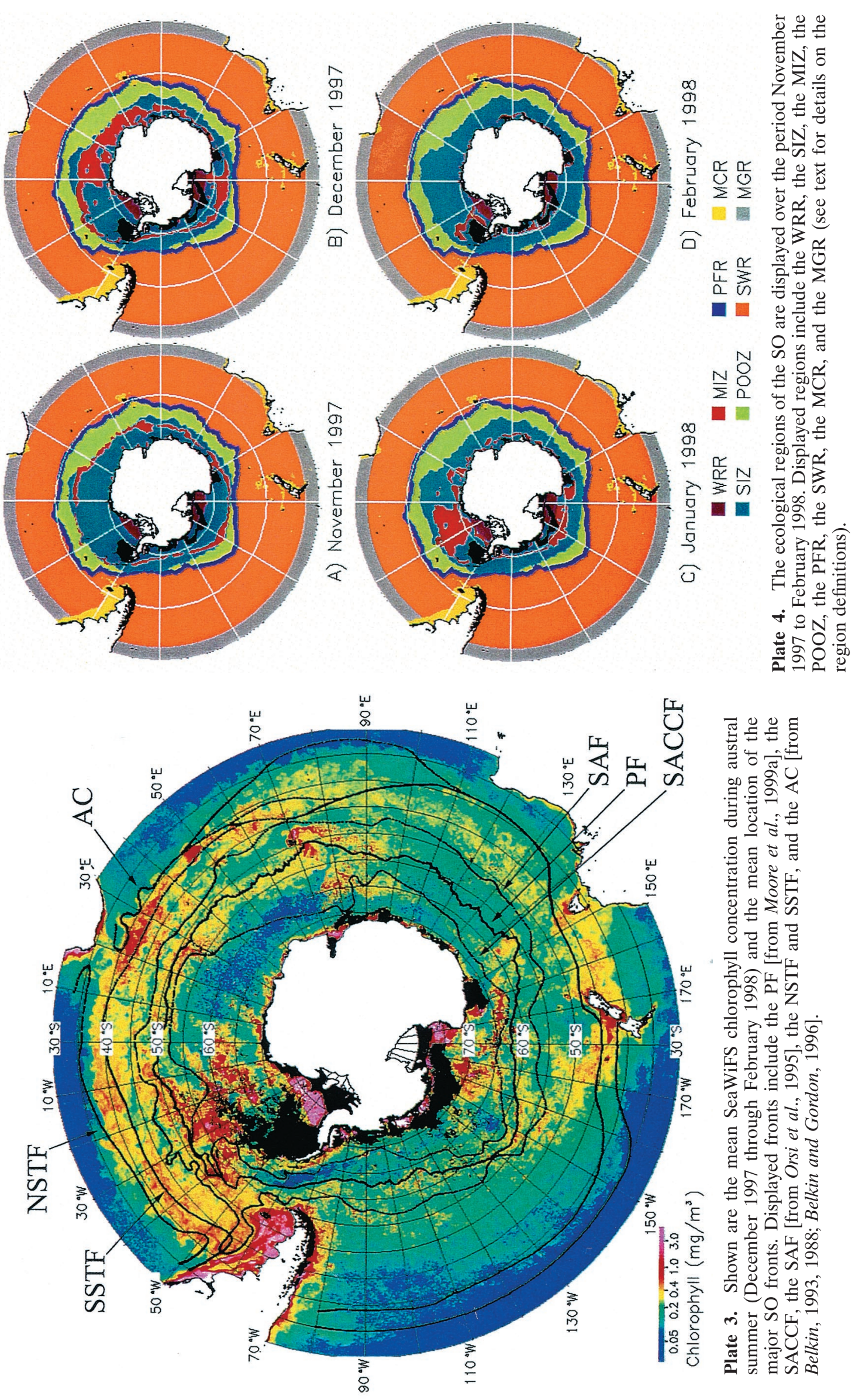
boundary is $\sim 5^{\circ}$ of latitude north of the mean position of the North Subtropical Front as defined by Belkin and Gordon [1996]. Technically, the North Subtropical Front marks the northern border of the Southern Ocean. The $30^{\circ} \mathrm{S}$ boundary is used to encompass northern meanders of this front. Mean latitude in the Indian sector of the North Subtropical Front is as far north as $32^{\circ}-33^{\circ} \mathrm{S}$ [Belkin and Gordon, 1996].

Primary production in the Southern Ocean is estimated using the vertically generalized production model (VGPM) of Behrenfeld and Falkowski [1997]. Satellite-derived estimates of surface chlorophyll, sea surface temperature, sea ice cover, and surface photosynthetically available radiation are used to drive this model. Our results are compared with several recent studies that used data from the CZCS to model primary production in Southern Ocean waters [Longhurst et al., 1995; Behrenfeld and Falkowski, 1997; Arrigo et al., 1998] as well as with estimates extrapolated from in situ measurements. We also compare our estimates of total primary production with estimates of seasonal net production based on atmospheric $\mathrm{O}_{2}$ variations [Bender et al., 1996].

\section{Methods and Materials}

SeaWiFS-derived estimates of surface chlorophyll concentrations for the period October 1997 through September 1998 were obtained from the Goddard Space Flight Center [McClain et al., 1998]. Daily level 3 standard mapped images of chlorophyll concentration (version 2) were compositeaveraged to produce weekly, monthly, seasonal, and annual means for the Southern Ocean. We compare these SeaWiFS estimates with data from the CZCS. Monthly CZCS composites processed with the global algorithm (GP) [Gordon et al., 1983] over the 1979-1986 period were obtained from NASA. We also derived monthly CZCS composites based on the Southern Ocean pigment (SOP) algorithm [Mitchell and HolmHansen, 1991] using the correction factors of Arrigo et al. [1994].

Monthly mean sea ice concentrations (NASA Team algorithm) from the Special Sensor Microwave Imager (SSM/I) DMSP-F13 satellite sensor for the years 1997-1998 were obtained from the Earth Observing System Data and Information System (EOSDIS) National Snow and Ice Data Center (NSIDC) Distributed Active Archive Center, University of Colorado, Boulder [National Snow and Ice Data Center, 1998]. Ice concentrations of $<5 \%$ were considered to be open water in our analysis. A minimum of $70 \%$ ice cover was used to determine the minimum (summer) sea ice extent. This value was chosen because significant phytoplankton biomass can accumulate in the water column at ice concentrations below $\sim 70 \%$ [e.g., Smith and Gordon, 1997]. All sea ice data were remapped to a $9 \mathrm{~km}$ equal angle grid.

The satellite chlorophyll data were analyzed by ecological region within the Southern Ocean. We divide the Southern Ocean into several ecological regions, including the Midlatitude Gyre Region (MGR), the Midlatitude Coastal Region (MCR), the Subantarctic Water Ring (SWR), the Polar Frontal Region (PFR), the Permanently Open Ocean Zone (POOZ), the Seasonal Ice Zone (SIZ), the Marginal Ice Zone (MIZ), and the Weddell-Ross Region (WRR). From the Antarctic Polar Front south to Antarctica these ecological regions are similar to those proposed by Tréguer and Jacques [1992] The WRR consists of the waters of the Weddell and Ross Seas that are south of $73^{\circ} \mathrm{S}$. This region is similar to the Coastal and
Continental Shelf Zone of Tréguer and Jacques [1992]. The SIZ is defined as areas with $>5 \%$ ice cover during August 1997 (maximum ice extent prior to growing season) and less $<70 \%$ ice cover during February 1998 (seasonal minimum ice extent). The MIZ is a subset of the SIZ where there has been recent melting of sea ice [Smith and Nelson, 1986]. We operationally define this ecologically important region as areas with $>50 \%$ sea ice cover the preceding month and $<50 \%$ ice cover in the current month. Previously, we have used $70 \%$ ice cover to define MIZ [Moore et al., 2000]. Here we use 50\% to include those areas that begin the growing season at $<70 \%$ ice cover. A wide range of cutoff values can be used in determining the MIZ ( 30-70\%) that give similar results because sea ice melts rapidly in the Southern Ocean, typically going from heavy to little ice cover in less than a month. The PFR is defined as all areas within $1^{\circ}$ of latitude of the mean path for the Antarctic Polar Front (PF) as defined by Moore et al. [1999a]. This location of the PF is based on satellite sea surface temperature data and thus marks the surface expression of the front. The PF has both surface and subsurface expressions [see Moore et al., 1999a]. Arguably, the surface expression has a stronger influence on the biota and is thus appropriate for use here. In any case the mean locations of the front based on surface and subsurface definitions are quite similar in most regions [Moore et al., 1999a]. The POOZ is the area north of the SIZ and south of the PFR.

The SWR is defined as the area from the PFR north to the Subtropical Fronts [Banse, 1996]. The northern border of this region is set at $35^{\circ} \mathrm{S}$, slightly north of the mean position of the North Subtropical Front as defined by Belkin and Gordon [1996]. North of this region, are the mid-ocean gyre systems of the Southern Hemisphere. This area, $30^{\circ}-35^{\circ} \mathrm{S}$, we term the MGR. To define open ocean patterns better we have excluded areas shallower than $500 \mathrm{~m}$ from the MGR, SWR, PFR, and POOZ areas using the topography data of Smith and Sandwell [1994]. These shallow coastal and shelf areas are collectively referred to as the MCR.

There is some overlap between these ecological regions. The WRR and the MIZ are subsets of the SIZ. We have excluded the WRR areas from the MIZ and SIZ. In the southwest Pacific and through Drake Passage the SIZ and MIZ overlap with the PFR. These areas have been included only within our SIZ and MIZ regions, and thus are excluded from the PFR.

Chlorophyll distributions are also compared with the mean positions of the major Southern Ocean fronts. We have used the mean path of Moore et al. [1999a] for the Antarctic PF. The positions of the Southern Antarctic Circumpolar Current Front (SACCF) and the Subantarctic Front (SAF) are from the analysis of Orsi et al. [1995]. The locations of the North Subtropical Front (NSTF) and South Subtropical Front (SSTF) and the Agulhas Current are from Belkin [1993, 1988] and Belkin and Gordon [1996]. The region from the SSTF to the NSTF is termed the Subtropical Frontal Zone (STFZ) [Belkin and Gordon, 1996]. The terminology and abbreviations used in defining the ecological regions and fronts are summarized in Table 1.

\section{Modeling Primary Production}

Primary production over monthly timescales was estimated using the VGPM [Behrenfeld and Falkowski, 1997]. The inputs to the VGPM are satellite-derived surface chlorophyll concentrations, sea surface temperatures, and photosynthetically 
Table 1. Abbreviations Used for the Various Southern Ocean Ecological Regions and Ocean Fronts

Abbrev-

iation

Definition

Ecological Regions

WRR Weddell-Ross Region, high-latitude Weddell and Ross Seas

SIZ Seasonal Ice Zone, $>5 \%$ ice cover August 1997 and $<70 \%$ ice cover February 1998

MIZ Marginal Ice Zone, $>50 \%$ ice cover in preceding month and $<50 \%$ in current month

POOZ Permanently Open Ocean Zone, north of SIZ and south of PFR

PFR Polar Frontal Region, area within $1^{\circ}$ latitude of Antarctic Polar Front mean location

SWR Subantarctic Water Ring, area north of PFR to $35^{\circ} \mathrm{S}$

MGR Midlatitude Gyre Region, area from $30^{\circ}$ to $35^{\circ} \mathrm{S}$

MCR Midlatitude Coastal Region, areas in MGR, SWR, PFR, and POOZ, where depth $<500 \mathrm{~m}$

\section{Ocean Fronts}

SACCF Southern Antarctic Circumpolar Current Front

PF Antarctic Polar Front

SAF Subantarctic Front

SSTF South Subtropical Front

NSTF North Subtropical Front

AC Aghulas Current

available radiation (PAR) at the water's surface [Behrenfeld and Falkowski, 1997]. Photoperiod, or day length, is calculated as a function of latitude and time of year. Monthly optimally interpolated sea surface temperature (SST) data at $1^{\circ}$ resolution were obtained from the National Centers for Environmental Prediction for the October 1997 to September 1998 period [Reynolds and Smith, 1994]. The SST data were remapped to a $9 \mathrm{~km}$ equal angle grid using linear interpolation between grid points.

The SST data are used to estimate the local maximum rate of primary production $\left(P_{\mathrm{opt}}^{B}\right)$ in the model according to the $P_{\text {opt }}^{B}$ versus SST regression of Behrenfeld and Falkowski [1997]. This empirical function is valid only for SST values from $-1^{\circ}$ to $29^{\circ} \mathrm{C}$. For areas where $\mathrm{SST}$ was $<-1.0^{\circ} \mathrm{C}, P_{\text {opt }}^{B}$ was set to the $-1.0^{\circ} \mathrm{C}$ value $\left(1.1 \mathrm{mg} \mathrm{C}(\mathrm{mg} \mathrm{Chl})^{-1} \mathrm{~h}^{-1}\right)$, and for SST above $29^{\circ} \mathrm{C}, P_{\text {opt }}^{B}$ was set to the $29.0^{\circ} \mathrm{C}$ value $\left(3.8 \mathrm{mg} \mathrm{C}(\mathrm{mg} \mathrm{Chl})^{-1}\right.$ $\mathrm{h}^{-1}$ ). In the SST data set, there often were no valid SST data at very high latitudes, mainly in the southern Weddell and Ross Seas. An SST value of $-1.0^{\circ} \mathrm{C}$ was used for computing primary production in these areas. Examination of the Pathfinder Program SST data set [Smith et al., 1996] revealed that mean SST values were below $-1.0^{\circ} \mathrm{C}$ in these areas during our study period.

Monthly surface PAR data for the years 1983-1984 were obtained from the SeaWiFS Project, and the data from the 2 years were averaged to produce a monthly mean (cloudcorrected) surface PAR, which was remapped to a $9 \mathrm{~km}$ equal angle grid with linear interpolation between grid points. Total water column chlorophyll was estimated from the satellite chlorophyll data using the equations of Morel and Berthon [1989]. Equation (3a) of Morel and Berthon [1989] was used for areas equatorward of $50^{\circ} \mathrm{S}$, and for latitudes $\geq 50^{\circ} \mathrm{S}$ (well-mixed waters) we used Morel and Berthon [1989, equation (5)]. Total water column chlorophyll was then used to estimate euphotic depth using Morel and Berthon [1989, equations (1a) and (1b)].

Two types of gaps were present in the monthly chlorophyll composites used to drive the primary production model. A small number of pixels had no data because of persistent cloud cover for the entire month. A second larger gap appears in the chlorophyll data at high latitudes seasonally because of the short day length and the inability of SeaWiFS to produce accurate chlorophyll estimates at very high solar angles. For this reason, there are little or no SeaWiFS data south of $\sim 45^{\circ}$ $50^{\circ} \mathrm{S}$ during austral winter. These gaps must be removed in some manner to avoid underestimating total primary production. There is high spatial variability in chlorophyll concentrations within the Southern Ocean. For this reason we have chosen to smooth the data over time rather than space. We treat the area equatorward of $40^{\circ} \mathrm{S}$ (weak seasonality) differently than the area poleward of $40^{\circ} \mathrm{S}$ (strong seasonality). Gaps in the data equatorward of $40^{\circ} \mathrm{S}$ were filled with the annual mean chlorophyll value over the October 1997 to September 1998 time period.

For the data gaps at latitudes $\geq 40^{\circ} \mathrm{S}$ we first averaged the monthly data from March and September 1998. The composite of these 2 months was then used to fill data gaps. During March and September (late fall and early spring) phytoplankton biomass (and chlorophyll concentrations) is low, and the system is likely light-limited. Using the composite of these 2 months thus represents a conservative method to fill in chlorophyll gaps that will not result in an overestimate of primary production. Most of the gaps filled were the seasonal type described above and occurred during austral winter. The few remaining gaps after this two-step process were filled by averaging all adjacent pixels with valid chlorophyll data. To prevent extending the chlorophyll data into areas with heavy sea ice cover (where primary production is negligible), we compared the smoothed monthly chlorophyll data with the monthly sea ice data and removed chlorophyll data in areas where sea ice concentration exceeded $70 \%$. The smoothed chlorophyll fields were used only in the calculations of primary production. All other analyses are based upon the original monthly composites of the level 3 chlorophyll data.

We estimate area-normalized production using two methods. In the first the mean production per square meter is calculated for all productive waters in a given region over monthly timescales. Productive waters are those with $<70 \%$ sea ice cover with some light available (during winter months) for primary production. The method gives results similar to what repeated ship surveys to the region would find and is probably the better value for cross-study comparisons. In the second method we divide the total production by the total area of a given region. This total area includes both productive and nonproductive waters and thus results in lower estimates of area-normalized production.

\section{Results}

\subsection{Satellite-Based Estimates of Chlorophyll in the Southern Ocean}

Several previous studies argued that the global processing algorithm (GP) used for the CZCS consistently underestimated surface chlorophyll concentrations in the Southern Ocean [Mitchell and Holm-Hansen, 1991; Sullivan et al., 1993; Arrigo et al., 1994]. An early comparison of a limited in situ data set from the Polar Frontal region near $170^{\circ} \mathrm{W}, 60^{\circ} \mathrm{S}$ with SeaWiFS data $(N=84)$ indicates generally good agreement between satellite and in situ measurements $\left(r^{2}=0.72\right.$, from a linear regression of shipboard versus satellite data) but also that the SeaWiFS algorithm (OC2) may underestimate abso- 
Table 2. Mean Chlorophyll Concentrations for Austral Spring/Summer Months (October-March) Over Several Latitudinal Bands ${ }^{\mathrm{a}}$

\begin{tabular}{lccc}
\hline & $\begin{array}{c}\text { SeaWiFS, } \\
\mathrm{mg} \mathrm{m}^{-3}\end{array}$ & $\begin{array}{c}\text { CZCS (GP) } \\
\mathrm{mg} \mathrm{m}^{-3}\end{array}$ & $\begin{array}{c}\text { CZCS (SOP), } \\
\mathrm{mg} \mathrm{m}^{-3}\end{array}$ \\
\hline $35^{\circ}-50^{\circ} \mathrm{S}$ & 0.29 & $0.15(0.21)$ & $0.37(0.52)$ \\
$50^{\circ}-90^{\circ} \mathrm{S}$ & 0.35 & $0.28(0.39)$ & $0.58(0.81)$ \\
$35^{\circ}-90^{\circ} \mathrm{S}$ & 0.34 & $0.22(0.31)$ & $0.49(0.69)$ \\
$30^{\circ}-90^{\circ} \mathrm{S}$ & 0.30 & $0.21(0.29)$ & $0.45(0.63)$ \\
\hline
\end{tabular}

${ }^{\mathrm{a} C Z C S}$ pigment values were computed with the original global chlorophyll algorithm (GP) [Gordon et al., 1983], and then the data were corrected to reflect the Southern Ocean Pigment (SOP) algorithm [Mitchell and Holm-Hansen, 1991] using the correction factors of Arrigo et al. [1994] before averaging. CZCS mean pigment values (shown in parentheses) were converted to chlorophyll using a mean chlorophyll/ phaeopigment ratio of 2.51 [Arrigo et al., 1994]. All values exceeding $10.0 \mathrm{mg} \mathrm{m}^{-3}$ were excluded during averaging.

lute Southern Ocean (SO) chlorophyll concentrations, although to a lesser extent than the CZCS [Moore et al., 1999b]. The SO pigment algorithm (SOP) was developed for CZCS data and resulted in chlorophyll concentrations higher than in the GP algorithm [Mitchell and Holm-Hansen, 1991].

To examine how well SeaWiFS is estimating chlorophyll concentrations in the SO, we compared mean chlorophyll concentrations from SeaWiFS with the CZCS data processed with the GP algorithm and with the SOP-corrected values (Table 2). Monthly means were composite-averaged over the October to March period. Mean chlorophyll concentrations were calculated for several latitudinal bands (Table 2). CZCS mean pigment values were converted to chlorophyll using a mean chlorophyll/phaeopigment ratio of 2.57 from Arrigo et al. [1994], which was calculated from an extensive in situ SO data set $(N=1070)$. As in previous averaging of CZCS data by Sullivan et al. [1993], we excluded areas of chlorophyll (or pigment) concentration $>10.0 \mathrm{mg} \mathrm{m}^{-3}$ (a small percentage of the total pixels, always $<0.43 \%$ ).

Several lines of evidence argue that the SeaWiFS global chlorophyll algorithm is doing a better job of estimating SO chlorophyll concentrations than was the CZCS. Table 2 shows that the SeaWiFS estimates for mean surface chlorophyll concentrations over all latitudinal bands lie between the CZCS GP and SOP estimates. These values can be compared with several means compiled from in situ data. Banse [1996] compiled a number of in situ data sets and estimated a seasonal peak within the SWR of $\sim 0.30 \mathrm{mg} \mathrm{m}^{-3}$. This is in good agreement with our mean October-March concentration of $0.29 \mathrm{mg} \mathrm{m}^{-3}$ for the $35^{\circ}-50^{\circ} \mathrm{S}$ region (Table 2) and a mean SWR December value of $0.30 \mathrm{mg} \mathrm{m}^{-3}$ (Plate 5). Fukuchi [1980] estimated mean chlorophyll concentrations over the latitudinal range $35^{\circ}-63^{\circ} \mathrm{S}$ to be 0.38 (east Indian sector December), 0.23 (west Indian sector late February/early March), and $0.27 \mathrm{mg} \mathrm{m}^{-3}$ (east Atlantic sector late February/early March). These values bracket the mean October-March SeaWiFS estimates (Table 2). The compilation of in situ data by Arrigo et al. [1994] estimated mean chlorophyll south of $30^{\circ} \mathrm{S}$ to be $0.42 \mathrm{mg} \mathrm{m}^{-3}$ $\left(0.58 \mathrm{mg} \mathrm{m}^{-3}\right.$ total pigments and a chlorophyll/phaeopigment ratio of 2.57). This value is higher than the SeaWiFS estimate but lower than the CZCS SOP estimate for latitudes $>30^{\circ} \mathrm{S}$ (Table 2).

The irregular temporal and spatial coverage of the in situ data likely bias mean in situ chlorophyll concentrations upward. Since chlorophyll concentrations tend to increase with latitude (Table 2), simple averaging over a latitudinal ship transect with regular spatial sampling would underestimate the total contribution from low-chlorophyll (Subantarctic) waters while giving equal weight to waters farther south (which are much smaller in their spatial extent, see Table 3). In addition, many in situ studies have focused on the biologically productive marginal ice zone where chlorophyll concentrations are much higher than SO averages (Plate 5 and Table 2). The distribution of in situ samples used by Arrigo et al. [1994] is weighted toward samples from $>50^{\circ} \mathrm{S}$ in the Atlantic and Indian sectors, with fewer samples from Subantarctic waters (the generally high-chlorophyll waters near New Zealand are well sampled) [see Arrigo et al., 1994, Figure 21]. This partially accounts for the higher mean chlorophyll concentration of 0.42 $\mathrm{mg} \mathrm{m}^{-3}$ [Arrigo et al., 1994].

By comparing the in situ values with the estimates from Table 2 it is evident that the CZCS GP algorithm did seriously

Table 3. Annual Primary Production Estimates Using the VGPM Model of Behrenfeld and Falkowski [1997] ${ }^{\mathrm{a}}$

\begin{tabular}{|c|c|c|c|c|}
\hline Region & $\begin{array}{l}\text { Productive } \\
\text { Waters, } \\
\mathrm{gC} \mathrm{m}^{-2} \mathrm{yr}^{-1}\end{array}$ & $\begin{array}{l}\text { All Waters, } \\
\mathrm{gC} \mathrm{m}^{-2} \mathrm{yr}^{-1}\end{array}$ & $\begin{array}{l}\text { Total Area, } \\
\text { million } \mathrm{km}^{2}\end{array}$ & $\begin{array}{c}\text { Total } \\
\text { Production, } \\
\mathrm{Gt} \mathrm{C} \mathrm{yr}^{-1}\end{array}$ \\
\hline MGR & 145.3 & 145.3 & $15.3(14.1)$ & $2.22(15.7)$ \\
\hline MCR & 528.8 & 505.8 & $2.57(2.4)$ & $1.30(9.2)$ \\
\hline SWR & 161.2 & 159.7 & $58.0(53.6)$ & $9.26(65.4)$ \\
\hline PFR & 82.0 & 73.2 & $4.89(4.5)$ & $0.385(2.7)$ \\
\hline POOZ & 62.3 & 58.5 & $8.70(8.0)$ & $0.509(3.6)$ \\
\hline SIZ & 50.8 & 29.1 & $16.2(15.0)$ & $0.472(3.3)$ \\
\hline WRR & 156.2 & 58.4 & $0.95(0.88)$ & $0.0555(0.39)$ \\
\hline $\begin{array}{l}\text { Southern Ocean } \\
\left(30^{\circ}-90^{\circ} \mathrm{S}\right)\end{array}$ & 148.5 & 131.0 & $108.2(100)$ & $14.17(100)$ \\
\hline $\begin{array}{l}\text { Southern Ocean } \\
\left(50^{\circ}-90^{\circ} \mathrm{S}\right)\end{array}$ & 82.2 & 62.4 & $45.7(42.2)$ & $2.85(20.1)$ \\
\hline MIZ & 54.2 & & $0-5.53(0-5.1)$ & $0.096(0.67)$ \\
\hline
\end{tabular}

${ }^{\text {a }}$ The percentage of total Southern Ocean primary production and ocean area accounted for is shown in parentheses for each region. Area-normalized production is calculated in two ways. The mean of all productive waters ( $<70 \%$ ice cover and some light available for photosynthesis) was calculated monthly and then summed (column 1). For calculating column 2, total production was divided by total area, which includes nonproductive waters (waters with $>70 \%$ ice cover or no light during austral winter). 
underestimate chlorophyll concentrations in the Southern Ocean [Mitchell and Holm-Hansen, 1991; Sullivan et al., 1993; Arrigo et al., 1994]. In contrast, the CZCS SOP algorithm values are higher than the in situ means. There is reason to believe that the CZCS SOP algorithm may have overestimated pigment concentration at low pigment concentrations. Arrigo et al. [1994] and Sullivan et al. [1993] compared CZCS data processed with the GP and SOP algorithms with a large in situ data set averaged over $1^{\circ}$ latitudinal bands. Both algorithms explained $71 \%$ of the variance seen in the in situ data set, with the SOP algorithm performing much better at higher pigment concentrations $\left(>\sim 0.6 \mathrm{mg} \mathrm{m}^{-3}\right)$ [Sullivan et al., 1993]. However, a regression of the SOP algorithm estimates of surface pigment versus in situ data had the equation $y=0.16+$ $0.905 x$ [Sullivan et al., 1993]. The large $y$ offset of $0.16 \mathrm{mg} \mathrm{m}^{-3}$ implies that the SOP algorithm may substantially overestimate pigment concentrations at lower chlorophyll (pigment) values $\left(<\sim 0.6 \mathrm{mg} \mathrm{m}^{-3}\right.$, i.e., by $50 \%$ where chlorophyll is $0.32 \mathrm{mg}$ $\left.\mathrm{m}^{-3}\right)$. Since over most of the SO chlorophyll concentrations do not exceed $0.6 \mathrm{mg} \mathrm{m}^{-3}$, use of the SOP algorithm may significantly overestimate chlorophyll concentration over much of the Southern Ocean. The SOP algorithm was developed from a data set from Antarctic Peninsula waters, with no total pigment values $<0.5 \mathrm{mg} \mathrm{m}^{-3}$ [Mitchell and Holm-Hansen, 1991]. In addition to the relatively high pigment values in Antarctic Peninsula waters, species-related pigment packaging effects in this region may not be representative of the whole SO. Some phytoplankton species such as Phaeocystis spp. are commonly found near the Antarctic Peninsula but typically are a minor component of the assemblages farther north. Thus application of this algorithm to all SO waters, particularly to lowchlorophyll Subantarctic waters, may overestimate chlorophyll concentrations. This highlights the problems with regional chlorophyll algorithms: namely, over what area should they be applied and how is the transition between regions managed?

In general, the SeaWiFS estimates are in better agreement with the in situ data than either CZCS data set. In part, this likely reflects the better temporal and spatial coverage by SeaWiFS. The largest gaps in the CZCS coverage occur in the low-chlorophyll waters of the Pacific sector [Comiso et al., 1993]. Large areas with no valid chlorophyll data also occur in the Indian sector (generally, a low-chlorophyll area; see Plates 1 and 3) during most austral summer monthly composites [Comiso et al., 1993]. These gaps may partially account for the higher mean values in the CZCS SOP data set. The good agreement between SeaWiFS and the in situ data argues strongly that the global chlorophyll algorithm is working well in the SO and, at least for Subantarctic waters, a regional algorithm is not necessary. At higher latitudes, SeaWiFS may be underestimating chlorophyll concentrations, although to a lesser extent than did the CZCS (Table 2) [Moore et al., 1999b].

\subsection{Chlorophyll Distributions in the Southern Ocean}

Monthly mean chlorophyll concentrations during austral spring and summer are shown in Plate 1 (areas in black had no valid chlorophyll data because of heavy sea ice or persistent cloud cover). Over most of the Southern Ocean, mean chlorophyll concentrations remain low despite the available nitrate and phosphate in surface waters (typically $<0.3-0.4 \mathrm{mg} \mathrm{m}^{-3}$, Plate 1). Very low chlorophyll values are seen north of $\sim 35^{\circ} \mathrm{S}$ within the subtropical gyres, in the southern half of Drake Passage $\left(\sim 80^{\circ}-60^{\circ} \mathrm{W}\right)$, and along $\sim 60^{\circ}-65^{\circ} \mathrm{S}$ between $20^{\circ}$ and $70^{\circ} \mathrm{E}$. This last area of low chlorophyll along $60^{\circ} \mathrm{S}$ marks the location of the Antarctic Divergence (AD), where strong upwelling occurs as a result of wind-driven divergence of surface waters [see Comiso et al., 1993]. This upwelling is clearly seen in oxygen concentrations at $100 \mathrm{~m}$ depth [Gordon et al., 1986]. The recent upwelling of these waters may account for the low-chlorophyll values observed in this area. Relatively low chlorophyll concentrations are also seen in the Indian sector $\sim 100^{\circ}-130^{\circ} \mathrm{E}$ at similar latitudes (Plate $1 \mathrm{~b}$ ) in another region of high winds and strong upwelling during austral summer [Comiso et al., 1993].

Phytoplankton blooms with chlorophyll values exceeding 1.0 $\mathrm{mg} \mathrm{m}^{-3}$ are seen in several areas. The highest values occur in coastal and shelf waters associated with Southern Ocean islands and continents. Thus high-chlorophyll values are seen surrounding and downstream of Kerguelen Island $\left(\sim 50^{\circ} \mathrm{S}\right.$, $70^{\circ} \mathrm{E}$ ), over the large shelf region on the east coast of South America, and in shelf regions associated with Africa, Australia, and New Zealand. High-chlorophyll values are also seen in the southern Weddell and Ross Seas and in other coastal Antarctic waters.

Monthly percentage sea ice cover for the November 1997 to February 1998 period is shown in Plate 2. During November the sea ice cover was still near its maximal winter extent over most of the Southern Ocean. There was a rapid melting of the seasonal sea ice cover during December and January (Plate 2). Most of this seasonal retreat of the sea ice cover occurs in the Weddell and Ross Seas (Plate 2). By comparing Plates 1 and 2, it can be seen that large phytoplankton blooms occur in areas where the sea ice has retreated in the Weddell Sea $\left(\sim 0-30^{\circ} \mathrm{W}\right.$, below $\left.\sim 60^{\circ} \mathrm{S}\right)$. Similar phytoplankton blooms are apparent in the Ross Sea $\sim 150^{\circ}-175^{\circ} \mathrm{W}$, below $\sim 60^{\circ} \mathrm{S}$ during December and below $\sim 65^{\circ} \mathrm{S}$ during January and February (compare Plates 1 and 2). It is important to note that phytoplankton blooms do not occur in all areas of sea ice retreat (compare Plates 1 and 2). For example, chlorophyll values remain very low between $\sim 10^{\circ}-60^{\circ} \mathrm{E}$ and $60^{\circ}-65^{\circ} \mathrm{S}$ despite the retreat of sea ice here over the November-January period (compare Plates 1 and 2). In other areas where ice cover is retreating, including parts of the Weddell and Ross Seas, chlorophyll concentrations also remain quite low $\left(<0.3 \mathrm{mg} \mathrm{m}^{-3}\right)$. Possible causes for these variations in ice edge bloom dynamics include variations in wind speed (and thus mixed layer depth), differential accumulation of atmospheric dust on the ice (which affects the amount of iron released to the water column during melting), and differences in Ekman-induced upwelling/ downwelling by the winds.

A large polynya opened in the southern Weddell Sea during early austral spring (Figures $2 \mathrm{a}$ and $2 \mathrm{~b}$ ). This early melting and consequent low summer ice extent in the southern Weddell Sea is very unusual [see Comiso and Gordon, 1998] and had a strong influence on the biota. A strong phytoplankton bloom developed within the polynya, which eventually encompassed the entire southern Weddell Sea (at latitudes $>70^{\circ} \mathrm{S}$ in the west and $>\sim 73^{\circ} \mathrm{S}$ in the east; Plates 1 and 3). Analysis of weekly maps of chlorophyll concentration and sea ice cover in this region indicates that this phytoplankton bloom developed as soon as the polynya opened up and persisted until the ninth week of 1998 when heavy sea ice cover rapidly covered the region. Comiso et al. [1990] also observed high chlorophyll concentrations persisting into March in the Weddell Sea with the CZCS. Reflection of light from ice- and snow-covered areas may bias the SeaWiFS data near the coast (within $\sim 50$ 
$\mathrm{km})$. However, the large size of this bloom in the southern Weddell Sea precludes its being an artifact of this type.

The remaining areas of high-chlorophyll values present in the monthly composites shown in Plate 1 are associated with the major fronts of the Southern Ocean. This is illustrated in Plate 3 where mean chlorophyll for the period December 1997 to February 1998 is shown along with the mean position of the major Southern Ocean fronts. Moving from high to low latitudes, the fronts depicted include the SACCF, the PF, the SAF, and the SSTF and NSTF. Also depicted in the region south of Africa is the Agulhas Current (AC).

Frontal-associated phytoplankton blooms at higher latitudes often occur in regions where the fronts interact with large topographic features [Moore et al., 1999b]. Thus persistent phytoplankton blooms are seen at the SACCF where it follows the Southeast Indian and Pacific-Antarctic Ridges $\left(\sim 160^{\circ} \mathrm{E}-\right.$ $\left.145^{\circ} \mathrm{W}\right)$ and along the Mid-Atlantic Ridge $\left(\sim 5^{\circ}-30^{\circ} \mathrm{E}\right)$ (Plate 3). Likewise, blooms at the PF can be seen along the PacificAntarctic Ridge (especially $\sim 145^{\circ}-160^{\circ} \mathrm{W}$ ), at the Falkland Plateau $\left(\sim 48^{\circ}-38^{\circ} \mathrm{W}\right)$, and along the Mid-Atlantic Ridge $\left(\sim 20^{\circ} \mathrm{W}-30^{\circ} \mathrm{E}\right)$.

Mesoscale physical-biological interactions where Southern Ocean fronts interact with topography can stimulate phytoplankton blooms [Moore et al., 1999b]. Two physical processes can result in an increased nutrient flux from subsurface waters to the surface layer in these regions. Vertical mixing may be increased by eddy actions as relative vorticity added to the water column by the large changes in ocean depth is dissipated [Moore et al., 1999b]. Second, in these regions of strong topographic interaction and just downstream, mesoscale meandering of the PF is intensified (at spatial scales $<100 \mathrm{~km}$ ) [Moore et al., 1999a, 1999b]. Such meandering leads to localized areas of upwelling and downwelling, which can strongly influence ocean biota [Flierl and Davis, 1993]. In addition, cross-frontal mixing could stimulate phytoplankton growth if different nutrients are limiting growth north and south of a particular front. For example, there is often a strong gradient in silicic acid concentrations across the PF, resulting in silica limitation of diatom growth to the north and, perhaps, iron limitation to the south [Tréguer and Jacques, 1992; Comiso et al., 1993]. Likewise, in the subtropical frontal region, nitrate availability likely limits phytoplankton growth rates in the gyre regions to the north, while iron limitation is more likely to the south [Sedwick et al., 1997].

Phytoplankton blooms at the SAF, SSTF, and NSTF are apparent in the Atlantic and Indian sectors but are generally lacking in the Pacific sector. Iron inputs at midlatitudes from atmospheric deposition are much lower in the Pacific compared with the Atlantic and Indian Oceans [Duce and Tindale, 1991]. Phytoplankton blooms are apparent in the vicinity of the SAF in the southeast Pacific during December 1997 (Plates 1b and 3). This is notable because phytoplankton blooms were not observed in this region with the CZCS sensor [Sullivan et al., 1993; Comiso et al., 1993].

Intense, persistent phytoplankton blooms are also associated with the $\mathrm{AC}$ and the SSTF in the African sector $\left(\sim 20^{\circ}-70^{\circ} \mathrm{E}\right)$ (Plates 1 and 3). The AC is influenced by topographic features in this region and interacts with, and at times merges with, the SSTF and the SAF [see Belkin and Gordon, 1996]. Comiso et al. [1993] also noted high chlorophyll values in this region. They attributed these phytoplankton blooms to the high eddy kinetic energy and possible current-induced upwelling in this region [Comiso et al., 1993].
One way to quantify these chlorophyll distributions is to divide the Southern Ocean into ecological regions. The MIZ covered a large area during December (5.5 million $\mathrm{km}^{2}$ ) and January (4.3 million $\mathrm{km}^{2}$ ). The location and shape of the MIZ changes considerably from month to month during the spring/ summer period (Plates $4 \mathrm{~b}$ and $4 \mathrm{c}$ ). The size of the MIZ was negligibly small over most of the rest of the year, reaching a minimum during May $1998\left(<1800 \mathrm{~km}^{2}\right)$.

Monthly mean chlorophyll concentrations within these ecological regions are displayed in Plate 5. Maximum chlorophyll levels were observed in the southern Weddell and Ross Seas, with a peak value of $5.5 \mathrm{mg} \mathrm{m}^{-3}$ during December 1997. High chlorophyll values were also observed in the MCR and within the MIZ. Mean chlorophyll values remained persistently low in the other regions, typically below $0.3 \mathrm{mg} \mathrm{m}^{-3}$ (although the PFR reached $0.43 \mathrm{mg} \mathrm{m}^{-3}$ during December; Plate 5).

Most regions showed a seasonal peak in chlorophyll concentration during December in phase with the seasonal solar radiation cycle. Exceptions to this pattern include the MCR, where little seasonality was observed, and the MGR, where there was an inverse pattern, with a minimum during austral summer. The seasonal pattern within the MGR is similar to that observed in the North Central Pacific Gyre at station ALOHA [Letelier et al., 1993]. In that region the seasonal cycle is primarily due to photoadaptation, with chlorophyll per cell in the surface layer increasing during winter months [Letelier et al., 1993]. Another possibility would be increased nutrient input (and phytoplankton biomass) during winter months in the MGR because of deeper wind mixing. The SIZ and MIZ regions had peak mean chlorophyll values in January and February, respectively (Plate 5).

\subsection{Primary Production in the Southern Ocean}

Primary production within the Southern Ocean, summed over seasonal timescales, as estimated with the VGPM is shown in Plate 6. The highest production occurs during austral summer, with maximum values in the coastal/shelf waters off of South America, Africa, Australia, and New Zealand and in the southern Weddell and Ross Seas (Plate 6b). Elevated production is also seen in the STFZ during all seasons in the Atlantic and Indian sectors and, to a much lesser extent, in the Pacific sector (compare Plates 3 and 6). This high primary production reflects the generally elevated chlorophyll values within the STFZ in the Atlantic and Pacific basins, combined with favorable SSTs (see discussion below) (Plates 1, 2, and 6).

At high latitudes, heavy sea ice cover and the seasonal insolation cycle lead to strong light limitation and negligible primary production below $60^{\circ} \mathrm{S}$ during austral winter (Plate $6 \mathrm{~d})$. The effect of sea ice distribution is also apparent during austral spring (compare Plates 2a and 6a). Some production occurs within the seasonal ice zone during austral fall prior to the seasonal sea ice expansion (Plate 6c). North of these highlatitude areas, significant primary production occurs during all seasons (Plate 6).

We next examine seasonal primary production patterns within the ecological regions described. Production per unit area was calculated using method 1 , averaging all pixels with some production in a given region (i.e., ice cover $<70 \%$ and some light available during winter months; Plate 7). Primary production per unit area was highest in the coastal/shelf areas of the WRR and MCR (Plate 7). All regions except the MGR show maximum production during austral summer, with the 
amplitude of this seasonal cycle increasing sharply with increasing latitude (Plate 7).

SST has a strong impact on the model estimates of primary production by setting the local maximum rate of primary production [Behrenfeld and Falkowski, 1997]. Within the lowchlorophyll regions, there is a latitudinal trend with the highlatitude (cold SST) regions having lower primary production values than regions farther north (warmer SST values) (Plate 7). Thus, despite having higher biomass the SIZ and MIZ regions generally have lower area-normalized production rates relative to the other regions (compare Plates 5 and 7). This temperature effect also accounts for the moderately high production values within the SWR despite generally low chlorophyll concentrations (Plates 5 and 7). Likewise, the warm SST values associated with the midlatitude gyres partially make up for the very low biomass/chlorophyll concentrations in this region (Plates 5 and 7). Finally, comparing the two coastal regions, the warmer SST values in the MCR raise production values here to higher levels than in the cooler but higher chlorophyll waters of the WRR (Plates 5 and 7).

If we examine total primary production by ecological region, it is apparent that the SWR accounts for most of the production within the SO because of its large areal extent and moderately high primary production during all seasons (Plate 8). A weak seasonal cycle is seen in the MCR and MGR regions, and a strong seasonal cycle is apparent with increasing latitude. Despite its high chlorophyll levels and primary production values the total carbon fixed within the WRR is small because of a relatively small spatial extent.

Annual primary production estimates for the various ecological regions of the SO are summarized in Table 3. Also shown in Table 3 are the percentages of the total SO primary production and area accounted for by each subregion. Note that area values in Table 3 are the maximum total area before correcting for sea ice cover and for complete light limitation at high latitudes during austral winter. For example, note that the total area below $50^{\circ} \mathrm{S}$ is 45.7 million $\mathrm{km}^{2}$; however, the maximum area over which the model was run was 41.3 million $\mathrm{km}^{2}$ (during February 1998, minimum ice extent), similar to previous studies [see Arrigo et al., 1998]. Annual area-normalized production was calculated by the two methods described in section 2. Total production (column 3) was calculated by summing the monthly production maps.

Note that the effective growing season for phytoplankton declines from 12 months per year at low latitudes to $<6$ months per year at the highest latitudes. Thus the WRR has higher production per unit area than the SWR over monthly timescales, but total production is similar over annual timescales (Plate 7 and Table 3). High chlorophyll (phytoplankton biomass) and growth during all seasons (in most regions) result in a high mean annual production within the MCR of $528.8 \mathrm{gC}$ $\mathrm{m}^{2} \mathrm{yr}^{-1}$, which accounts for $9.2 \%$ of total SO production but only $2.4 \%$ of the area (Plate 7 and Table 3 ). The bulk of primary production comes from the midlatitude regions, with areas poleward of $50^{\circ} \mathrm{S}$ accounting for only $20.1 \%$ of total primary production while occupying $42.2 \%$ of the total area (Table 3). This reflects a shorter growing season at high latitudes, which is a function of strong light limitation during winter months. Total primary production in Antarctic Surface Waters, i.e., areas from the PF south to Antarctica, is $1.42 \mathrm{Gt}$ $\mathrm{C} \mathrm{yr}^{-1}$ from a maximum area of 30.74 million $\mathrm{km}^{2}$ (Table 3: $\mathrm{WRR}+\mathrm{SIZ}+\mathrm{POOZ}+\mathrm{PFR})$.

\section{Discussion}

The patterns in chlorophyll distribution described here are qualitatively similar to those of previous studies of the SO with the CZCS sensor [Sullivan et al., 1993; Comiso et al., 1993]. There are some notable differences, most likely due to the sparse CZCS coverage in this region. Extensive phytoplankton blooms were observed in the southeast Pacific sector during December 1997 (Plate 1b). No blooms were seen in this region in the CZCS data, and silica limitation was suggested as a possible cause [Sullivan et al., 1993; Comiso et al., 1993]. Silica limitation or perhaps iron limitation may account for the lack of blooms here in January and February (Plate 1). The plume of elevated chlorophyll values extending downstream from the Kerguelen Plateau (beginning at $\sim 70^{\circ}$ E; Plate 1 b) was larger than observed previously [Sullivan et al., 1993; Comiso et al., 1993]. The bloom in the southern Weddell Sea (Plate 1b) was much larger and extended farther west than was observed with the CZCS, likely because of the unusually strong summer ice melt during this season [Sullivan et al., 1993; Comiso et al., 1993; Comiso and Gordon, 1998].

At high latitudes $\left(>50^{\circ} \mathrm{S}\right)$, maximum production was estimated within the WRR at $1.39 \mathrm{gC} \mathrm{m}^{-2} \mathrm{~d}^{-1}$ during December 1997, with an annual production of $156 \mathrm{gC} \mathrm{m}^{-2} \mathrm{yr}^{-1}$ (Table 3). Several studies have measured primary production on the Ross Sea shelf at rates $>1.0 \mathrm{gC} \mathrm{m}^{-2} \mathrm{~d}^{-1}$ [Smith et al., 1996; Bates et al., 1998]. Nelson et al. [1996] combined in situ data from several seasons to estimate an annual primary production on the Ross Sea shelf of $142 \mathrm{gC} \mathrm{m}^{-2} \mathrm{yr}^{-1}$. The modeling study of Arrigo et al. [1998] used CZCS chlorophyll concentrations (corrected with the SOP algorithm) to estimate primary production of 3.94 and $1.44 \mathrm{gC} \mathrm{m}^{-2} \mathrm{~d}^{-1}$ for the Ross and Weddell shelf areas, respectively, during December. By combining all shelf areas for the months of December and January, they estimated the average production to be $\sim 1.5 \mathrm{gC} \mathrm{m}^{-2} \mathrm{~d}^{-1}$ [Arrigo et al., 1998].

Wefer and Fischer [1991] estimated annual primary production in the Polar Front Zone to be $83 \mathrm{gC} \mathrm{m}^{-2} \mathrm{yr}^{-1}$ on the basis of sediment trap data in the Atlantic sector, similar to our PFR estimate of $82.0 \mathrm{gC} \mathrm{m}^{-2} \mathrm{yr}^{-1}$ (Table 3). For the combined POOZ and SIZ regions they estimated annual primary production to be $21.5 \mathrm{gC} \mathrm{m}^{-2} \mathrm{yr}^{-1}$ [Wefer and Fischer, 1991]. This is considerably less than our estimates of 62.3, 54.2, and 50.8 $\mathrm{gC} \mathrm{m}^{-2} \mathrm{yr}^{-1}$ for the POOZ, MIZ, and SIZ, respectively (Table $3)$. If nonproductive waters are included in calculating areanormalized production (total production divided by maximum SIZ extent; Table 2), mean SIZ production drops to $29.1 \mathrm{gC}$ $\mathrm{m}^{-2} \mathrm{yr}^{-1}$ (Table 3). Arrigo et al. [1998] estimated annual primary production to be $\sim 130 \mathrm{gC} \mathrm{m}^{-2}$ in pelagic waters $\left(>50^{\circ} \mathrm{S}\right)$, $\sim 141 \mathrm{gC} \mathrm{m}^{-2}$ for the MIZ, and $\sim 184 \mathrm{gC} \mathrm{m}^{-2}$ for shelf waters (annual mean production calculated from Arrigo et al. [1998, Table 3] using our method 1).

Comparisons between our MIZ values and those of Arrigo et al. [1998] are difficult because of the different definitions used in defining this region. Different percentage ice cover cutoffs were used, and in addition, we excluded the high biomass areas of the southern Weddell and Ross Seas (the WRR) from our MIZ region. The maximum estimated MIZ production rates during January was $0.336 \mathrm{gC} \mathrm{m}^{-2} \mathrm{~d}^{-1}$ (see Plate 7). This is considerably lower than the rates estimated by Arrigo et al. [1998] and the estimates of Smith and Nelson [1986] of 0.571 $\mathrm{gC} \mathrm{m}^{-2} \mathrm{~d}^{-1}$ for the Weddell Sea and $0.962 \mathrm{gC} \mathrm{m}^{-2} \mathrm{~d}^{-1}$ for the Ross Sea based on in situ measurements. Our estimate of 

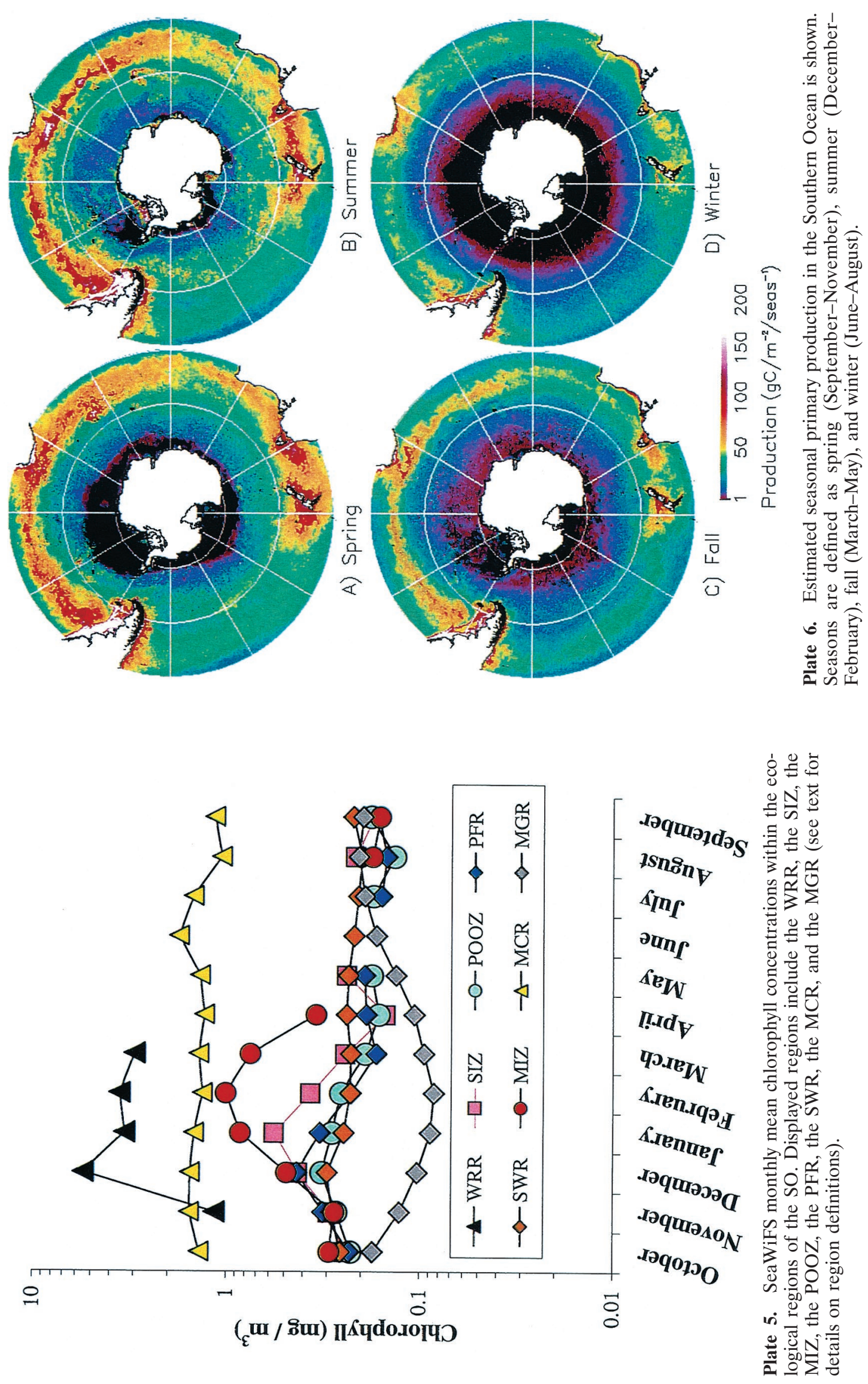

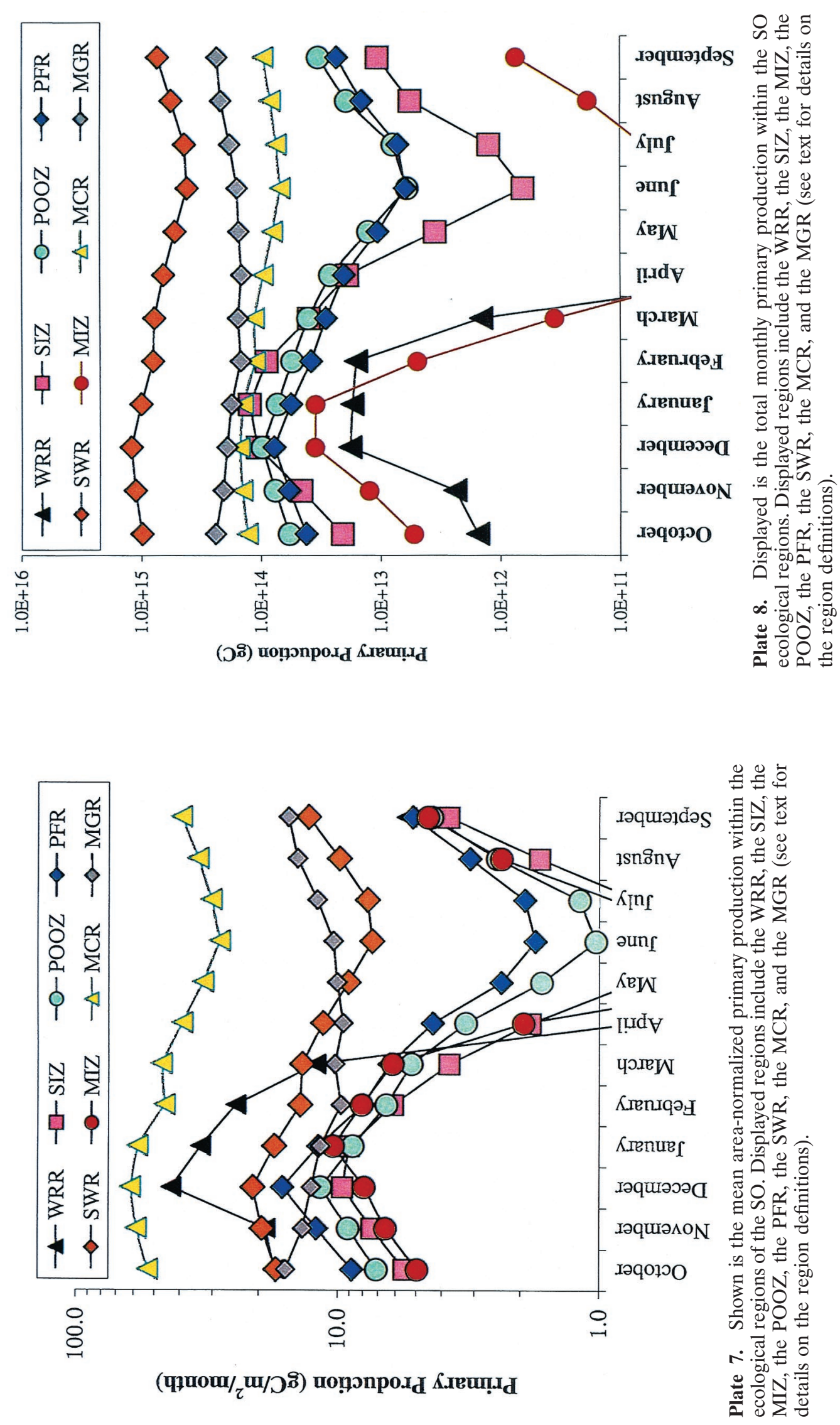
annual total MIZ production (0.10 Gt C; Table 3) is also considerably less than previous estimates (0.38 Gt C [Smith and Nelson, 1986] and 0.41 Gt C [Arrigo et al., 1998]). Our total SIZ production was 0.472 Gt C (Table 3).

Several factors could account for the differing estimates of MIZ productivity. The differing definitions for the MIZ resulted in larger areal extent in both of these other studies. Maximum MIZ extent (during December) was 6 [Arrigo et al., 1998] and 6.84 million $\mathrm{km}^{2}$ [Smith and Nelson, 1986], while our value was 5.5 million $\mathrm{km}^{2}$. We excluded the high-productivity WRR from our MIZ areas. If WRR areas are not excluded, our total MIZ production is increased to $0.114 \mathrm{Gt}$ C. Smith and Nelson [1986] used the average of the Weddell and Ross Sea in situ measurements to calculate total production. These areas had the strongest ice edge blooms during the 1997-1998 season and much higher chlorophyll values than in other areas of ice retreat (Plates 1 and 2). Thus applying a production mean computed from these areas may overestimate production elsewhere. Mean MIZ production during December in the Weddell Sea $\left(0-70^{\circ} \mathrm{W}\right.$, not excluding WRR areas) was $0.744 \mathrm{gC}$ $\mathrm{m}^{-2} \mathrm{~d}^{-1}$, comparable to the Smith and Nelson [1986] estimates but more than twice our average for the whole MIZ during this month. Mean MIZ production in the Ross Sea $\left(160^{\circ} \mathrm{E}-140^{\circ} \mathrm{W}\right.$, not excluding WRR areas) was $0.401 \mathrm{gC} \mathrm{m}^{-2} \mathrm{~d}^{-1}$. Thus spatial and interannual variability could be important factors. A third factor that may be relevant is the use of SST to estimate local maximum production rates in the VGPM. The regression of $P_{\mathrm{opt}}^{B}$ versus temperature of Behrenfeld and Falkowski [1997] may underestimate maximum production rates in cold ice edge surface waters of the Antarctic as samples of these waters are minimally represented in their in situ data set.

Our estimate for total primary production at latitudes $>30^{\circ} \mathrm{S}$ was 14.2 Gt C yr ${ }^{-1}$ (Table 3). Longhurst et al. [1995] estimated primary production within different regions of the global ocean using CZCS data (GP algorithm) combined with a primary production model. The total production within the four SO regions was $8.2 \mathrm{Gt} \mathrm{C} \mathrm{yr}^{-1}$ [Longhurst et al., 1995]. This total does not include coastal production or the production from mid-ocean gyre regions below $30^{\circ} \mathrm{S}$. Adding production from these other regions, after multiplying by the approximate fraction, which is below $30^{\circ} \mathrm{S}$, increases the total to $\sim 11.2 \mathrm{Gt} \mathrm{C}$ $\mathrm{yr}^{-1}$ [Longhurst et al., 1995, Figure 2, Table 2].

Our estimated total primary production for all areas at latitudes $>=50^{\circ} \mathrm{S}$ was $2.9 \mathrm{Gt} \mathrm{C} \mathrm{yr}^{-1}$ (Table 3). Longhurst et al. [1995] estimated total production of $2.24 \mathrm{Gt} \mathrm{C} \mathrm{yr}^{-1}$ for their Antarctic and Antarctic Polar regions. These regions account for most of the area below $50^{\circ} \mathrm{S}$. If primary production from half of their Subantarctic region is added (approximate portion below $50^{\circ} \mathrm{S}$ ), the total is increased to $4.01 \mathrm{Gt} \mathrm{C} \mathrm{yr}^{-1}$ [Longhurst et al., 1995]. Arrigo et al. [1998] estimated production for all waters $>50^{\circ} \mathrm{S}$ at $4.4 \mathrm{Gt} \mathrm{C} \mathrm{yr}^{-1}$ on the basis of total pigments (with the SOP correction to CZCS data), with lower estimates

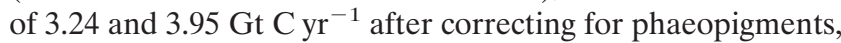
which were not distinguishable from chlorophyll with the CZCS. A recent run of the VGPM model using the SOP algorithm corrections for the CZCS data and correcting for sea

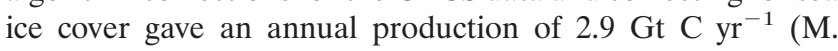
Behrenfeld, personal communication, 1999).

These model estimates are heavily dependent on the satellite surface chlorophyll concentrations used. If SeaWiFS underestimates surface chlorophyll concentrations, our estimate of primary production would be too low. Alternatively, as discussed in section 4.1 , the SOP algorithm may have overesti- mated chlorophyll concentrations over much of the SO. If so, estimates based on these chlorophyll concentrations would be too high. The model of Arrigo et al. [1998] was based on the satellite data and the available nitrate and silicic acid but did not allow for iron limitation of phytoplankton growth rates. This likely leads to overestimates of production, particularly in open ocean waters [see Moore et al., 2000, and references therein].

The satellite-based estimates can be compared with estimates that extrapolate from a limited number of in situ observations. This approach lacks the high spatial coverage of the satellite data. Smith [1991] estimated total production south of the PF at 1.23 Gt C. Priddle et al. [1998] estimated production south of the SAF at $\sim 1.7 \mathrm{Gt} \mathrm{C} \mathrm{yr}^{-1}$, or $\sim 30-40 \mathrm{~g} \mathrm{C}^{-2} \mathrm{yr}^{-1}$, on the basis of estimates of carbon consumption by top level predators and the production needed to support it and on seasonal nutrient drawdown at several locations. These methods may have underestimated total production. Extrapolation from a limited number of locations is unlikely to be accurate given the large degree of regional and latitudinal variability demonstrated in this paper. In their food web model, Priddle et al. [1998] did not allow for direct sinking of diatoms out of the surface layer, which may be an important loss process and would increase production estimates. Estimates based on nutrient drawdown may underestimate production because of recycling within the surface layer.

Seasonal variations of atmospheric oxygen concentrations can be used to estimate large-scale oceanic production and global-scale carbon sinks [Keeling et al., 1993; Bender et al., 1996]. Our total production estimates (scaled by appropriate $f$ ratios) can be compared with these atmospheric-based estimates of seasonal net production. Bender et al. [1996] examined seasonal $\mathrm{O}_{2} / \mathrm{N}_{2}$ ratios in the Southern Hemisphere and argued that a seasonal minimal net oceanic production of 2.6-3.6 molC m $\mathrm{m}^{-2} \mathrm{yr}^{-1}$ was required to account for the seasonal atmospheric $\mathrm{O}_{2}$ variations based on the model results of Keeling et al. [1993]. This represents a seasonal net production in temperate latitudes of $\sim 31.2-43.2 \mathrm{gC} \mathrm{m}^{-2}$, with a mean of $\sim 36 \mathrm{gC} \mathrm{m}^{-2}$ [Keeling et al., 1993; Bender et al., 1996]. The temperate band of Keeling et al. [1993] consisted of latitudes from $23.6^{\circ}$ to $44.4^{\circ} \mathrm{S}$. Total ocean area over this band is $\sim 6.598 \times 10^{13} \mathrm{~m}^{2}$. Thus the net production estimates of Bender et al. [1996] represent a total seasonal net production over this band of $\left(6.598 \times 10^{13}\right) \times 36=2.37 \times 10^{15} \mathrm{gC}$, or 2.37 $\mathrm{Gt} \mathrm{C}$. This is a rough estimate that ignores latitudinal mixing in the atmosphere across bands. However, such mixing is limited, as evidenced by the much weaker seasonal cycle in oxygen at low latitudes and the opposite phasing of the seasonal cycles in the Northern and Southern Hemispheres [Keeling et al., 1998].

The mean Southern Hemisphere seasonal cycle in atmospheric $\mathrm{O}_{2}$ increases over the 4 month period OctoberJanuary, with an amplitude of $\sim 70$ per meg, and is largely the result of oceanic processes below $30^{\circ} \mathrm{S}$ [Keeling et al., 1998]. Approximately $81 \%$ of the seasonal cycle at midlatitudes is due to net oceanic production [Keeling et al., 1993]. A similar seasonal amplitude in oxygen is seen at the South Pole [Keeling et al., 1998]. Of the 3 years examined by Bender et al. [1996] the 1993-1994 season most closely resembled the long-term mean cycle at southern midlatitudes [see Keeling et al., 1998]. The 1997-1998 seasonal atmospheric oxygen cycle was nearly identical to the mean pattern of Keeling et al. [1998] (R. Keeling, personal communication, 1999). The 1993-1994 estimate for minimal net oceanic production by Bender et al. [1993] was 36 
$\mathrm{gC} \mathrm{m}^{-2}$, which, as calculated above, would imply a seasonal net oceanic production of $2.37 \mathrm{Gt}$ C. On the basis of several considerations, Bender et al. [1993] argued that actual oceanic net production was higher than their minimum estimates by a factor of $\sim 1.5$. This net production would increase the total net production estimate to $3.56 \mathrm{Gt}$ C. Can our estimated primary production at latitudes below $30^{\circ} \mathrm{S}$ account for a seasonal net production of 2.37-3.56 Gt C over the October 1997 to January 1998 period?

Our estimated total primary production for the area $30^{\circ}$ $60^{\circ} \mathrm{S}$ over the 4 month period October 1997 through January 1998 was $6.2 \mathrm{Gt} \mathrm{C}$ or $71.4 \mathrm{gC} \mathrm{m}^{-2}$. The seasonal net production implied by the atmospheric $\mathrm{O}_{2}$ data would then represent an $f$ ratio (the ratio of new to total production) in the range of $0.38-0.57$. Typical $f$ ratios for these mainly Subantarctic waters range from 0.3 to 0.5 [Banse, 1996]. Seasonal net production can exceed short-term estimates of new production for a number of reasons [see Bender et al., 1996]. Seasonal net production can have high $f$ ratios relative to annual new production because some of the organic $\mathrm{C}$ formed but not respired during spring/summer months is respired later in the season. In addition, some fixed organic matter sinks and is respired below the surface mixed layer (but still in the euphotic zone) and thus might not influence spring/summer $\mathrm{O}_{2}$ outgassing. Thus, taking these factors into account, primary production in SO midlatitude waters is sufficient to account for the observed seasonal cycle in atmospheric $\mathrm{O}_{2}$ documented previously [Bender et al., 1996; Keeling et al., 1998].

SeaWiFS data are providing the most comprehensive look yet at the distribution of chlorophyll in the SO. Several other satellite ocean color sensors are scheduled to go into orbit over the next decade. Thus SeaWiFS is laying the baseline for a long-term continuous time series of global surface chlorophyll measurements. Combining satellite data with ocean circulation, climate, and biogeochemical models will provide valuable tools to improve our understanding of the ocean ecosystems and the global carbon cycle.

Acknowledgments. The authors would like to thank Dave Nelson, Jim Richman, Ted Strub, and Ricardo Letelier for helpful comments and suggestions. The authors would also like to thank the SeaWiFS project (code 970.2) and the Distributed Active Archive Center (code 902) at the Goddard Space Flight Center, Greenbelt, MD 20771, for the production and distribution of the ocean color data, respectively. These activities are sponsored by NASA's Earth Science Enterprise Program. We would also like to thank the EOS Distributed Active Archive Center (DAAC) at National Snow and Ice Data Center (Boulder, $\mathrm{CO}$ ) for the sea ice data, the National Center for Environmental Prediction for the interpolated SST data, and the SeaWiFS project for providing the surface radiation data. This work was funded by a NASA Earth System Science Fellowship (J.K.M.) and by NASA/EOS grant NAGW-4596 (M.R.A.).

\section{References}

Arrigo, K. R., and C. R. McClain, Spring phytoplankton production in the western Ross Sea, Science, 266, 261-263, 1994.

Arrigo, K. R., C. R. McClain, J. K. Firestone, C. W. Sullivan, and J. C. Comiso, A comparison of CZCS and in situ pigment concentrations in the Southern Ocean, NASA Tech. Memo., 104566, 30-34, 1994.

Arrigo, K. R., D. Worthen, A. Schnell, and M. P. Lizotte, Primary production in Southern Ocean Waters, J. Geophys. Res., 103, 15,58715,600, 1998.

Banse, K., Low seasonality of low concentrations of surface chlorophyll in the Subantarctic water ring: Underwater irradiance, iron, or grazing?, Prog. Oceanogr., 37, 241-291, 1996.

Bates, N. R., D. A. Hansell, C. A. Carlson, and L. I. Gordon, Distri- bution of $\mathrm{CO}_{2}$ species, estimates of net community production, and air-sea $\mathrm{CO}_{2}$ exchange in the Ross Sea polynya, J. Geophys. Res., 103, 2883-2896, 1998.

Behrenfeld, M. J., and P. G. Falkowski, Photosynthetic rates derived from satellite-based chlorophyll concentration, Limnol. Oceanogr., 42, 1-20, 1997.

Belkin, I. M., Main hydrological features of the central South Pacific, in Pacific Subantarctic Ecosystems (in Russian), edited by M. E. Vinogradov and M. V. Flint, pp. 21-28, Nauka, Moscow, 1988. (English translation, pp. 12-17, N. Z. Transl. Cent., Wellington, 1997.)

Belkin, I. M., Frontal structure of the South Atlantic, in Pelagicheskie Ekosistemy Yuzhnogo Okeano (in Russian), edited by N. M. Voronina, pp. 40-53, Nauka, Moscow, 1993.

Belkin, I. M., and A. L. Gordon, Southern Ocean fronts from the Greenwich meridian to Tasmania, J. Geophys. Res., 101, 3675-3696, 1996.

Bender, M., T. Ellis, P. Tans, R. Francey, and D. Lowe, Variability in the $\mathrm{O}_{2} / \mathrm{N}_{2}$ ratio of Southern Hemisphere air, 1991-1994: Implications for the carbon cycle, Global Biogeochem. Cycles, 10, 9-21, 1996.

Coale, K. H., et al., A massive phytoplankton bloom induced by an ecosystem-scale iron fertilization experiment in the equatorial $\mathrm{Pa}$ cific Ocean, Nature, 383, 495-501, 1996.

Comiso, J. C., and A. L. Gordon, Interannual variability in summer sea ice minimum, coastal polynyas and bottom water formation in the Weddell Sea, Antarctic Sea Ice: Physical Processes, Interactions, and Variability, Antarct. Res. Ser., vol. 74, edited by M. O. Jeffries, pp. 293-315, AGU, Washington, D. C., 1998.

Comiso, J. C., N. G. Maynard, W. O. Smith Jr., and C. W. Sullivan, Satellite ocean color studies of Antarctic ice edges in summer and autumn, J. Geophys. Res., 95, 9481-9496, 1990.

Comiso, J. C., C. R. McClain, C. W. Sullivan, J. P. Ryan, and C. L. Leonard, Coastal Zone Color Scanner pigment concentrations in the Southern Ocean and relationships to geophysical surface features, J. Geophys. Res., 98, 2419-2451, 1993.

de Baar, H. J. W., J. T. M. de Jong, D. C. E. Bakker, B. M. Löscher, C. Veth, U. Bathmann, and V. Smetacek, Importance of iron for plankton blooms and carbon dioxide drawdown in the Southern Ocean, Nature, 373, 412-415, 1995.

Duce, R. A., and N. W. Tindale, Atmospheric transport of iron and its deposition in the ocean, Limnol. Oceanogr., 36, 1715-1726, 1991.

Eppley, R. W., and B. J. Peterson, Particulate organic matter flux and planktonic new production in the deep ocean, Nature, 282, 677-680, 1979.

Flierl, G. R., and C. S. Davis, Biological effects of Gulf Stream meandering, J. Mar. Res., 51, 529-560, 1993.

Fukuchi, M., Phytoplankton chlorophyll stocks in the Antarctic Ocean, J. Oceanogr. Soc. Jpn., 36, 73-84, 1980.

Gordon, A. L., E. Molinelli, and T. Baker, Southern Ocean Atlas, Amerind, New Delhi, India, 1986.

Gordon, H. R., D. K. Clark, J. W. Brown, O. B. Brown, R. H. Evans, and W. W. Broenkow, Phytoplankton pigment concentrations in the Middle Atlantic Bight: Comparison of ship determinations and CZCS estimates, Appl. Opt., 22, 20-36, 1983.

Gordon, R. M., K. H. Coale, and K. S. Johnson, Iron distributions in the equatorial Pacific: Implications for new production, Limnol. Oceanogr., 42, 419-431, 1997.

Keeling, R., R. Najjar, M. Bender, and P. Tans, What atmospheric oxygen measurements can tell us about the global carbon cycle, Global Biogeochem. Cycles, 7, 37-67, 1993.

Keeling, R. F., B. B. Stephens, R. G. Najjar, S. C. Doney, D. Archer, and $M$. Heimann, Seasonal variations in the atmospheric $\mathrm{O}_{2} / \mathrm{N}_{2}$ ratio in relation to the kinetics of air-sea gas exchange, Global Biogeochem. Cycles, 12, 141-163, 1998.

Letelier, R. M., R. R. Bidigare, D. V. Hebel, M. Ondrusek, C. D. Winn, and D. M. Karl, Temporal variability of phytoplankton community structure based on pigment analysis, Limnol. Oceanogr., 38 , 1420-1437, 1993.

Longhurst, A., S. Sathyendranath, T. Platt, and C. Caverhill, An estimate of global primary production in the ocean from satellite radiometer data, J. Plankton Res., 17, 1245-1271, 1995.

Martin, J. H., Glacial-interglacial $\mathrm{CO}_{2}$ change: The Iron hypothesis, Paleoceanography, 5, 1-13, 1990.

Martin, J. H., S. E. Fitzwater, and R. M. Gordon, Iron in Antarctic waters, Nature, 345, 156-158, 1990a. 
Martin, J. H., S. E. Fitzwater, and R. M. Gordon, Iron deficiency limits phytoplankton growth in Antarctic waters, Global Biogeochem. Cycles, 4, 5-12, 1990b.

McClain, C. R., M. L. Cleave, G. C. Feldman, W. W. Gregg, S. B. Hooker, and N. Kuring, Science quality SeaWiFS data for global biosphere research, Sea Technol., September 10-16, 1998.

Minas, H. J., and M. Minas, Net community production in "high nutrient-low chlorophyll" waters of the tropical and Antarctic Oceans: Grazing vs. iron hypothesis, Oceanol. Acta, 15, 145-162, 1992.

Mitchell, B. G., and O. Holm-Hansen, Bio-optical properties of Antarctic Peninsula waters: Differentiation from temperate ocean models, Deep Sea Res., 38, 1009-1028, 1991.

Moore, J. K., M. R. Abbott, and J. G. Richman, Location and dynamics of the Antarctic Polar Front from satellite sea surface temperature data, J. Geophys. Res., 104, 3059-3073, 1999a.

Moore, J. K., M. R. Abbott, J. G. Richman, W. O. Smith, T. J. Cowles, K. H. Coale, W. D. Gardner, and R. T. Barber, SeaWiFS satellite ocean color data from the Southern Ocean, Geophys. Res. Lett., 26, 1465-1468, 1999b.

Moore, J. K., M. R. Abbott, J. G. Richman, and D. Nelson, The Southern Ocean at the last glacial maximum: A strong sink for atmospheric carbon dioxide, Global Biogeochem. Cycles, 14, 455475, 2000.

Morel, A., and J. F. Berthon, Surface pigments, algal biomass profiles, and potential production in the euphotic layer: Relationships reinvestigated in view of remote-sensing applications, Limnol. Oceanogr., 34, 1545-1562, 1989.

National Snow and Ice Data Center, Passive Microwave Derived Monthly Polar Sea Ice Concentration Time Series, nsidc@kryos. colorado.edu, Distrib. Active Arch. Cent., Univ. of Colo., Boulder, 1998.

Nelson, D. M., D. J. DeMaster, R. B. Dunbar, and W. O. Smith Jr., Cycling of organic carbon and biogenic silica in the Southern Ocean: Estimates of water column and sedimentary fluxes on the Ross Sea continental shelf, J. Geophys. Res., 101, 18,519-18,532, 1996.

Orsi, A. H., T. Whitworth III, and W. D. Nowlin Jr., On the meridional extent and fronts of the Antarctic Circumpolar Current, Deep Sea Res., Part I, 42, 641-673, 1995.

Priddle, J., M. J. Boyd, E. J. Whitehouse, E. J. Murphy, and J. P. Croxall, Estimates of Southern Ocean primary production: Constraints from predator carbon demand and nutrient drawdown, $J$. Mar. Sys., 17, 275-288, 1998.

Reynolds, R. W., and T. M. Smith, Improved global sea surface temperature analyses using optimum interpolation, J. Clim., 6, 114-119, 1994.

Sedwick, P. N., P. R. Edwards, D. J. Mackey, F. B. Griffiths, and J. S. Parslow, Iron and manganese in surface waters of the Australian subantarctic region, Deep Sea Res., Part I, 49, 1239-1253, 1997.
Smith, E., J. Vasquez, A. Tran, and R. Sumagaysay, Satellite-derived sea surface temperature data available from the NOAA/NASA Pathfinder Program, Eos Trans. AGU Electron. Suppl., April 2, 1996. (Available as http://www.agu.org/eos_elec/95274e.html)

Smith, W. H. F., and D. T. Sandwell, Bathymetric prediction from dense satellite altimetry and sparse shipboard bathymetry, J. Geophys. Res., 99, 21,803-21,824, 1994.

Smith, W. O., Jr., Nutrient distributions and new production in polar regions: Parallels and contrasts between the Arctic and Antarctic, Mar. Chem., 35, 245-257, 1991.

Smith, W. O., Jr., and L. I. Gordon, Hyperproductivity of the Ross Sea (Antarctica) Polynya during austral spring, Geophys. Res. Lett., 24, 233-236, 1997.

Smith, W. O., Jr., and D. M. Nelson, Importance of ice edge phytoplankton production in the Southern Ocean, BioScience, 36, 251257, 1986.

Smith, W. O., Jr., D. M. Nelson, G. R. DiTullio, and A. R. Leventer, Temporal and spatial patterns in the Ross Sea: Phytoplankton biomass, elemental composition, productivity and growth rates, J. Geophys. Res., 101, 18,455-18,465, 1996.

Sullivan, C. W., C. R. McClain, J. C. Comiso, and W. O. Smith Jr., Phytoplankton standing crops within an Antarctic ice edge assessed by satellite remote sensing, J. Geophys. Res., 93, 12,487-12,498, 1988.

Sullivan, C. W., K. R. Arrigo, C. R. McClain, J. C. Comiso, and J. Firestone, Distributions of phytoplankton blooms in the Southern Ocean, Science, 262, 1832-1837, 1993.

Takeda, S., Influence of iron availability on nutrient consumption ratio of diatoms in oceanic waters, Nature, 393, 774-777, 1998.

Tréguer, P., and G. Jacques, Dynamics of nutrients and phytoplankton, and fluxes of carbon, nitrogen, and silicon in the Antarctic Ocean, Polar Biol., 12, 149-162, 1992.

van Leeuwe, M. A., R. Scharek, H. J. W. de Baar, J. T. M. de Jong, and L. Goeyens, Iron enrichment experiments in the Southern Ocean: Physiological responses of plankton communities, Deep Sea Res., Part II, 44, 189-208, 1997.

Wefer, G., and G. Fischer, Annual primary production and export flux in the Southern Ocean from sediment trap data, Mar. Chem., 35, 597-613, 1991.

M. R. Abbott, College of Oceanic and Atmospheric Sciences, Oregon State University, 104 Ocean Administration Building, Corvallis, OR 97331-5503.

J. K. Moore, Advanced Studies Program, National Centers for Atmospheric Research, P. O. Box 3000, Boulder, CO 80307-3000. (jkmoore@cgd.ucar.edu)

(Received August 16, 1999; revised July 19, 2000; accepted July 26, 2000.) 